\title{
Socio-Cultural Aspect of Thriftiness
}

\author{
Irina Lyskova \\ Economics and Management department \\ Komi Republican Academy of State Service and Administration \\ Syktyvkar, Russia
}

\begin{abstract}
The article contains general overview on the history of managerial and economic thoughts in Russia in late XIXth - early XXth century in the context of the main problems of personal management development, socio-cultural aspects of human resources management and quality management. Particular attention is paid to the characteristics of thriftiness as understood by a famous Russian scientist I.I. Yanzhul from the point of view of the analysis of socio-cultural, socio-economic and socio-psychological backgrounds of personal management.
\end{abstract}

Keywords-human resources management; self-management; quality management; history of managerial and economic thought; scientific heritage of I.I. Yanzhul

\section{INTRODUCTION}

Analysis of current socio-economic processes of Russian society development grounds the importance of personal management theory and practice. Nowadays there are still no common approaches to characteristics of personal management as a phenomenon even though the most practically significant bases of personal management (socioeconomic and socio-psychological) were about to be defined at the end of the XIXth century. Modern life shows a great demand for adequate evaluation of personal management in the processes of individual activity and human resources quality management in organization and society on the whole $[1 ; 2 ; 3 ; 4]$.

\section{THE SOURCES OF SELF-MANAGEMENT IN RUSSIA}

It is important to mention that at the end of the XIXth and at the beginning of the XXth century a profound work was carried on, which intended to systematize the research in different science fields. Socio-economic works had their own integrant place in the system. In 1902 'A Guide in Russian economical literature' was prepared for publishing by economist and Professor P.I. Georgievsky. It paid special attention to works on theory and history of Economics, problems of economic history and up-to-date economic situation. The Guide contained a catalogue of works and journal articles laid out in a stated order.

What is more, it is essential to accentuate the activity of scientific community in Moscow and St. Petersburg in organizing self-education for Russian youth in various fields of science including Economics. What is meant here is the activity of teams under the direction of Moscow University Professor P.N. Milyukov and St. Petersburg University
Professor N.I. Kareev. P.N. Milyukov was the head of Moscow Commission for home reading establishment at the Technical knowledge development Society. N.I. Kareev founded the Department for self-education assistance in the Pedagogical museum of military-training institutions. These scientific groups carried on a hard work in preparing 'Home Reading Programs' (Moscow, from 1894) and 'Reading for Self-education Programs' (St. Petersburg, from 1895). The Programs were being published till 1914 with edition of dozens of thousands copies and were extremely in demand by people interested in self-education $[5 ; 6]$.

Such an active work was initiated by a famous Russian scientist, economist, recognized specialist in the field of financial law, Professor of the Law Department at Moscow University I.I. Yanzhul (1846 - 1914). In 1892 I.I. Yanzhul with the help of P.N. Milyukov, P.V. Preobrazhensky, L.Z. Morokhovets and other scientists compiled and edited 'A Book About Books: Glossary Index for Choosing Books in the Significant Fields of Knowledge', in two volumes [12]. This work contained a catalogue of literature in Physics and Mathematics, Science and Social Science such as Theology, History, Philosophy, Archeology, Ethnography, Philology, Law and Economics and were addressed mostly to people having secondary education and students of universities.

It should be noted that the term 'management' and especially 'self-management' were not commonly used in Russian science till 90s of the XXth century. But it does not mean that managerial and economic thought had nothing to deal with the content of personal management. In regard to this, the end of XIXth - early XXth century are of special interest. The analysis of the main development trends in selfmanagement helps to understand this phenomenon as a complex of theoretical and practical aspects of life which are focused on self-development, education and even more selfeducation, constant intellectual, ethical and aesthetic selfimprovement and professional self-realization $[4 ; 5 ; 6 ; 7 ; 8$; $9 ; 10]$.

\section{I.I. YANZHUL'S VIEWS ON ECONOMIC FREEDOM OF A PERSON}

I.I. Yanzhul's scientific heritage is rich and multi-faceted. His journalistic works on acute problems of modern (to his time) Western and Russian society arouse particular interest. I.I. Yanzhul paid great attention to individual and social aspects of personal management, including socio-cultural 
and socio-economic issues, analyzed value priorities of Western Europeans, Americans and Russians. [13].

\section{A. The Main Characteristic Features of Western European and North American Personal Management Model}

Among the exceptional characteristics of Western European and North American personal management model they recognize self-support which is the ability to solve private economical tasks, fend for oneself, provide financial stability and security independently.

Duty-bound nearly every year I.I. Yanzhul visited the countries of Western Europe or America, lived in England and carrying out a research noticed the specifics of Western European approach to financial problem solving. He wrote: 'I am concerned now that we, Russians, Americans and Western Europeans, have a profound ... psychic difference which is due to centuries of different history and which determines all our relationship in life and even views on the same subject... Every English person, every Western European dealing with need and adversities is used to relying on self-support, their own work and energy. Only if all the effort and diligence is over, they decide to resort to outside help, to the help of the government or society. Any other behavior is an exception which is disapproved. This is the reason why mendicancy is widely despised. "Reckon on yourself, think about yourself, help yourself' - is a common rule, whereas 'please, help, give alms' is a rare and undesirable exception to the rule..." [14, p. 152].

\section{B. The Distinctive Features of Russian Mentality}

I.I. Yanzhul points out that a different norm is inherent to Russian people. One of distinctive features of Russian mentality is fatalism which determines submission to fate, troubles, hopelessness, suffering and hardship. At the same time there is a desire to be content with what you have.

According to I.I. Yanzhul a Russian man "is ready to surrender the need and, instead of taking care of himself, he is waiting for a miracle, outside help, no matter where this help comes from: the treasury chests or private purse; and he is inclined to think that such assistance is likely to be a gift and he will not have to pay for it in any way..." [14, p. 155]. This is exactly a feature of Russian life and mentality which I.I. Yanzhul calls 'darovschinka' - willingness to get things free of charge. The author demonstrates sharply negative attitude to this social disease common in Russia. He calls for the formation of new consciousness based on the belief that "common well-being is based on work rather than on dole and a person tends to cherish only what he got with some force or sacrifice ...". "Darovschinka" is harmful in the way that it "weakens the human energy necessary to achieve goals," teaches people idleness, irresponsibility, justifies laziness and unwillingness to work. I.I. Yanzhul, being aware of the specifics of the economic foundations of the traditional Russian way of life, underlines the importance of "sense and practice of self-support," which is an integral part of labor activity [14, pp. 159-161].

\section{The Basis of Human'S Economic Life}

In I.I. Yanzhul's point of view labor activity and selfsupport are the basis of people's economic life. But in Russia the attitude to both of them is rather contradictory. So he accentuates the reasons which significantly impede socioeconomic development of the country and determine the backwardness of Russia from Western countries. The reasons include the specificity of the bureaucratic apparatus of the Russia and the long existence of serfdom. A great part of the intellectuals and educated class in Russia was occupied in civil service and did not feel any need to worry about tomorrow's issues, they were confident in the stability of their economic situation. I.I. Yanzhul noted: “... the official always expects to increase his prosperity or hopes that when he is retired, the government will recall his merits and will provide for him and his family in case of his death" $[17$, p. 450].

As for ordinary people, personal and economic dependence of the peasants had a very negative impact on the pace of development of the country: productive forces development, development of entrepreneurship and economic initiative among the masses. It was fundamentally contrary to the economic and political structure of the Russian state. What is more, in the field of industry for a long time there remained models of socio-economic relations which were similar to serfdom.

The presence of these two extremes in the economic system of the Russian society gave rise to symptoms of mismanagement, extravagance, denying the need for thriftiness and concerns about the future. I.I. Yanzhul characterizes this fact in the following way: "On the one hand for so many years people in their earnings and personally depended on landlords and their grace, and, of course, could not think of the future, take care and in the right way to save money for the future. A landlord could take from a peasant nearly everything he had earned but he had to ... take care of him in case of an accident or unpredictable circumstances. On the other hand, the nobility and other estates, being used to exploit the results of other people's labor and income, had no need to restrain themselves in expenses, control their desires and they were used to spending all that they received. Of course, with the fall of serfdom, this habit permanently rooted deep into our society and any other behavior seems strange to Russian people, "bourgeois" and not characteristic to Russian broad nature!'[17, p. 451].

\section{Thriftiness as a Basis of Economic Culture of a Person}

Exploring the specifics of individual and social consciousness of different nations I.I. Yanzhul emphasizes that thriftiness is a very important economic factor that contributes to the "development and progress" of nations. He studies a number of extremely important issues related to the characteristic of frugality as a social and cultural phenomenon in individual and social context, in the aspects of material and spiritual culture.

In order to create adequate models of behavior that meet the requirements of the time and the main directions of 
socio-economic development of Russia, the scientist points out that to solve many economic problems it is necessary to "start from the very beginning" solving the task of economic education and upbringing of the younger generation.

One of socially important practical issues, from the point of view of I.I. Yanzhul was the question of the role of thriftiness in individual and social life. He was sincerely convinced in absolute necessity of thriftiness for personal and social well-being and described thriftiness as "aspiration not to spend the entire capital that a person gains but to save a part of it for the future. The increase of wealth and general well-being is inevitably linked to the development of thriftiness" [16, p. 1].

\section{CONCLUSION}

Actualizing the experience of traditional civilized nations, especially the United States, I.I. Yanzhul paid attention to the fact that people there are taught to handle money at school. Special training courses reveal the "economic value" of ordinary everyday objects and actions and form the "habit of saving money and spending it wisely".

The task of moral education of young people in terms of economics is extremely important in this respect. The paradox lies in the fact that all these truths are as old as the hills. It was already Plato who pointed out four main human virtues: "wisdom" (prudence), "courage" (fortitude), "moderation" (abstinence or self-restraint), and "justice" (righteousness). All these postulates are directly related to the issues of human economic activity. Proper organization of economic education and upbringing of children and young people will enable the youth to become "thrifty, honest, modest, practical, and later thinking over the ways of spending money ... This has a positive impact not only on saving money but also on well-being of future citizens" $[17$, p. 457]

The main problem is that the undisputed and generally accepted in the western world values of thriftiness, moderation in spending money and desires, self-control, ability to resist temptations, and development of will and character do not find widespread support and recognition in Russian society. The conclusion is rather complicated.

The key motive for the people of Western mentality is the desire to preserve their moral-self, "with no resorting to some humiliating requests as people who possess nothing have to do..." [17, p. 456]. For Russian people, unfortunately, this state has long been considered normal. A man had no personal freedom, no right to dispose the property [15]. Even today, we can observe the negative attitudes that prevent development of personal initiative in dealing with economic issues. So, serious work on the formation of individual personal management system is required in terms of awareness not only of spiritual values but also in of material well-being and financial stability. The importance of these tasks in the current socio-economic conditions is unlikely to require multiple arguments.

\section{REFERENCES}

[1] Blinov, A.O. (2014). Moral economy and liberalism of Russia. The Russian Academic Journal. No. 1 (27). 26-29.

[2] Blinov, A.O. (2014). The moral problem of poverty in the Russian economy. The world of new economy. No. 1. 35-41.

[3] Blinov, A.O., Lyskova, I.E. (2016). Conceptual basis of forming of ethical culture business-processes in modern organization. Journal of economy and entrepreneurship. No. 2-1 (67-1). 931-937.

[4] Blinov, A.O., Lyskova, I.E. (2016). Self-management in modern reengineering of human resources. Journal of economy and entrepreneurship. No. 3-1 (68-1). 622-626.

[5] Blinov, A.O., Lyskova, I.E. (2016). International public activity in favor of spreading university education as a social innovation in the period from the end of $19^{\text {th }}$ up to the beginning of $20^{\text {th }}$ centuries. Almamater. Vestnik vysshei shkoly. No. 10. 85-93.

[6] Lyskova, I.E., (2014). The philosophic and sociological roots of selfmanagement. In the World of Scientific Discoveries. Human and Social Sciences. Krasnoyarsk. No. 7.2 (55). 757-776.

[7] Lyskova, I.E. (2015). Moral responsibility and moral freedom in the aspect of self-management. Economics and management: analysis of tendencies and perspective of development. Anthology of the XX International scientific-practical Conference, Novosibirsk. 13-17.

[8] Lyskova, I.E, (2015). Psychological aspect of self-management. Economic psychology: modern problems and perspective of development. Anthology of the XV International scientific-practical Conference. Sant-Petersburg. 188-194.

[9] Lyskova, I.E, (2015). Thrift as a sociocultural phenomenon. Economy and modern management. Novosibirsk. 49-57.

[10] Lyskova, I.E, (2015). Russian intelligentsia about the role of the social movement University Extension in the process of the education system development and personal management in Russia at the end 19 th - the beginning 20th century. Intelligentsia and World. No. 2. 17-33.

[11] Lyskova, I.E, (2015). The influence of the University Extension Movement on the development of system of education and selfmanagement in the countries of Western Europe, North America and Russia: gender aspect. Women in Russian society. No. 2 (75).105-118

[12] Yanzhul I.I. (1892). A Book About Books: Glossary Index for Choosing Books in the Significant Fields of Knowledge. Moscow. V.1. 310 p.

[13] Yanzhul I.I. (1896). From psychology of the peoples. Economical meaning of time and space //. Yanzhul I, Yanzhul E. Leisure Hours. Essays and Images on economic, social and literary issues. Moscow. 20-56.

[14] Yanzhul I.I. (1904). We too are susceptible to "darovschinka" // Essays on public education, economic policy and public life. St. Petersburg. 152-161.

[15] Yanzhul I.I. (1904). Two measurements of a Russian man // Essays on public education, economic policy and public life. St. Petersburg. 415-419.

[16] Yanzhul I.I. (1904). Thrifty children // Essays on public education, economic policy and public life. St. Petersburg.1-10.

[17] Yanzhul I.I. (1904). Child thriftiness in Russia // Essays on public education, economic policy and public life. St. Petersburg. 449-476. 